\title{
The Wretched African Traditionalists in Kenya: The Challenges and Prospects of Customary Law in the New Constitutional Era
}

\author{
f Osogo Ambani* ${ }^{*}$ Ochieng Ahaya**
}

\begin{abstract}
The modern African judge will be the first to acknowledge that, in many senses, the problems faced by British judges in colonial Africa have not vanished. Almost one hundred percent of the African judiciary is now African. But even though there is no longer the gross disparity of national origin between a judge and his community, a judge often does not come from the particular locality whose ethnic law he is administering. A part from this ethnic question, there is an enormous educational and cultural gap between a senior judge with a western education and the ordinary families he may deal with. Thus, the judicial system may have moved from a problem of race and ethnicity to one of class. ${ }^{1}$
\end{abstract}

\section{Introduction and context}

A 'religious cult' emerged in Kenya during the colonial epoch (1930s) which (religion) preached that indigenous Africans might never reclaim their heritage as long as Western values dominated the socio-political milieu. At the height of its activity in the years after the Second World War, the main tenets of this faith were that the Europeans should leave Kenya and that natives should return to the ways and religion of their ancestors. ${ }^{2}$ The leaders of the movement were

Ocran M 'The clash of legal cultures: The treatment of indigenous law in colonial and post-colonial Africa' Akron Law Review (2006), 480.

2 Vermouth P 'Rural rebels: Audrey Wipper and Dini ya Msambwa' 13 International Journal of African Historical Studies 2, 313.

* $\quad$ LLD (Cand), LLM (UP); LLB (UoN), Lecturer, Strathmore Law School

** PhD, MA (Moi Univ); BED (KU), Lecturer, Masinde Muliro University of Science, Agriculture and Technology 
Elijah Masinde, Joash Walumoli, Benjamin Wekuke and Donnish Kakimayu. Dini ya Musambwa, as the religion came to be famed, fought for the reinstatement of African customary law. One of the main items it proclaimed was the practice of polygamy observed in most Kenyan societies. An administrator during the colonial era, Teddy Eggins, in 1949, saw this faith as:

The cult of the ancestral spirits... one of those storms, or perhaps a mere shower, of fanaticism - partly social, partly religious, partly nationalistic - which passes from time to time across the landscape of history. ${ }^{3}$

Based on similar sentiments, the colonial government proscribed the faith. In a recent interview with journalists, its current leader lamented: "just the way Masinde was frustrated and harassed by the Government during the colonial days and after independence, we have equally not been spared."4 Not only have successive governments troubled this religious group, but also, its principal pillar - the reinstatement of African customary law - has faced consistent yet subtle onslaughts from amongst others, the State itself. This investigation concerns this important pillar of the proscribed faith of Dini ya Musambwa. The contribution examines whether the major aspiration of this faith and others, of having indigenous Africans enjoy and observe their cultural and religious usages and practices, embedded in their customary laws, has been achieved more than seven decades after the faith was proscribed.

We argue that apart from the Christian faith, customs, laws and values consistent with it, any other religion or custom is certain to find the Kenyan legal system not very hospitable. Religious and cultural traditions not analogous to Christianity or English common law stand to face stiff opposition and obstructions, firstly, from the Constitution itself, then general Acts of Parliament and judicial precedents, Western traditions and even international human rights instruments to which Kenya is party. This remains the case despite nascent constitutional stipulations providing that every person has the right to participate in the cultural life of choice ${ }^{5}$ and to enjoy the person's culture. ${ }^{6}$ The Constitution also makes it illegal to "compel another person to perform, observe or undergo any cultural practice or rite"?

Bellers V, 'What Mr Sanders really did' www.britishempire.co.uk/article/sanders/sanderschapter21. $\underline{\mathrm{htm}}$ on 8 November 2006.

'A sect that believes in God, but not Jesus or Holy Spirit' East African Standard 1 November 2004.

Article 44(1), Constitution of Kenya (2010).

Article 44(2)(a), Constitution of Kenya (2010).

Article 44(3), Constitution of Kenya (2010). 
This investigation is conducted through the eyes of African customary law, against which multi-faceted battles have been wedged, most of which it has lost. African customary law is defined here to imply:

$[\mathrm{r}]$ ules of custom, morality, and religion that the indigenous people of a given locality view as enforceable either by the central political system or authority, in the case of very serious forms of misconduct, or by the various social units such as the family... ${ }^{8}$

Reference to African customary law could, therefore, very well be reference to traditional custom, morality or religion. It is, indeed, true that the values of western society are embodied in common law; even as values of traditional African society are embodied in their customary law. ${ }^{9}$

\section{The state of customary law and practices in Kenya's legal system}

The rise of colonial rule in Kenya was the beginning of the fall of African traditional religion, custom and law. For an in depth appreciation of this development, we discuss African customary law first through its historical phases - the pre-colonial period; the colonial period; and the post-colonial period - before alluding to the limitations it currently faces by dint of the Constitution of Kenya 2010, Acts of Parliament, international law, case law and common law.

\section{African customary law before colonialism}

African social and political systems did not experience a linear trajectory throughout the pre-colonial period. One could argue that before the fifteenth century, the African hinterlands practiced largely pure, indigenous or authentic traditional lifestyles. As shown below, matters changed drastically once the 'visitors' put their imprint on the continental landscape.

\section{African customary law and systems before visitation}

Africans had their own authentic methods of operating governance and justice systems which are difficult to reconcile with the now dominant western approaches. Although some traditional societies such as the Wanga of Kenya, Baganda of Uganda, and Zulu of South Africa qualified to be called 'states',

Ocran, 'The clash of legal cultures', 467-468. Emphasis supplied.

van Doren JW 'Death African style: The case of SM Otieno' American Journal of Comparative Law (1988), 330 . 
most others lacked a centralised political authority, and functioned without codified law or regular systems of taxation. ${ }^{10}$ Instead,

[s]ocial cohesion was obtained through custom and consensus, not only within families but within clans and, as far as possible, between clans. Internally within the group there was minimal use of force and coercion, and greater reliance on traditional precedent. ${ }^{11}$

Regulation in the traditional African sense therefore entailed more than just coercive laws or formal policies issuing from official governance structures. There was room for customs and related moral principles which were often exerted without physical police or tangible criminal sanctions.

Almost every community had its method of celebrating marriage, divorce, death and conducting other social transactions. Even criminal law was explained in terms of these usages. The Maasai, for instance, practiced self-help in which it was the prerogative of a murdered person's family to go after the murderer subject to the possibility of accepting the so called 'blood money' as civil damages, in lieu of death. ${ }^{12}$ The people of Somali extraction have a similar tradition, which survives to date. ${ }^{13}$

It is also important to mention that pre-colonial African systems were predominated by religion which permeated nearly all aspects of life to the extent of making the separation of faith from action illusory. ${ }^{14}$ Practitioners of traditional African religion have been known to experience their faith long before birth, throughout life, and way after death. As John Mbiti ably demonstrates,

[W] here the African is, there is his religion: he carries it to the fields where he is sowing seeds or harvesting a new crop; he takes it with him to the beer party or to attend a funeral cer-

\footnotetext{
Mazrui AA, The Africans: A triple heritage, Little, Brown and Co., Boston and Toronto, 1986, 68.

Mazrui, The Africans, 69.

Ocran, 'The clash of legal cultures', 473-474.

On this basis a lawyer of a complainant family recently moved the High Court in Kenya to terminate a murder trial citing the fact that: "The two families have sat and some form of compensation has taken place wherein camels, goats and other traditional ornaments were paid to the aggrieved family. Actually one of the rituals that have been performed is said to have paid for blood of the deceased to his family as provided for under the Islamic law and customs. These two families have performed the said rituals, the family of the deceased is satisfied that the offence committed has been fully compensated to them under the Islamic laws and customs applicable in such matters and in the foregoing circumstances, they do not wish to pursue the matter any further be it in court or any other forum ...". As if to corroborate the above averments, Abdow Alio Ibrahim, the deceased's father, further testified in an affidavit before court: "it's worth noting that it goes against our tradition to pursue the matter any further and/or testify against the accused person once we have received full compensation in the matter of which we already have ... it's our instruction that the matter and/or court case be withdrawn as our family wishes to put a stop to the matter." Republic $v$ Mohamed Abdow Mohamed, Criminal Case No 86 of 2011.

14 For fuller treatment, see Magesa L, What is not sacred: African spirituality, Acton Publishers, Nairobi, 2013.
} 
emony; and if he is educated, he takes religion with him to the examination room at school or in the university; if he is a politician he takes it to the house of parliament. ${ }^{15}$

Since traditional religion accompanied its subjects in virtually every undertaking, the law in pre-colonial societies has to be cast against a context whereby "belief in the supernatural, and law may be fused and mutually supportive". ${ }^{16}$

\section{African customary systems after visitation}

By the sixteenth century, Islam and Christian values had begun to slowly percolate the 'dark continent'. At the East African Coast, Portuguese and other civilisations had already begun to have influence. Arab traders and European missionaries had not only extended economic and political muscle, but also religious and cultural influence. They introduced unique civilisations, and their legacy included inputting into the local languages, cultures, political and social systems, agriculture, architecture, trade, and religion, amongst others. ${ }^{17}$ In West Africa;

$[T]$ he religion of Islam had been firmly rooted in many societies in sub-Saharan Africa since the fifteenth century. Islam entered Hausa land in the early fourteenth century. About 40 Wangarawa traders brought Islam with them, and during the reign of Muhammad Rumfa between 1463 and 1499, Islam was firmly rooted in Kano. ${ }^{18}$

At the same time, imperialists had begun peeping at the African tent with the view to occasioning phenomenal transformation through systematic imposition of novel social, political and legal systems in which their distinct values were embedded. According to Lord Lugard - the author of colonialism in east, west

15 Mbiti JS, African religions and philosophy, Heinemann, Nairobi, 1969, 142.

16 van Doren JW, 'African tradition and western common law: A study in contradiction' in Ojwang JB and Mugambi JNK (eds) The SM Otieno case: Death and burial in modern Kenya, Nairobi University Press, 1989, 128.

17 See for instance, Martin BG, 'Arab migrations to East Africa in medieval times' 7 International Journal of African Historical Studies 3, (1974) 367. Also, Oliver R,Atmore A, Africa since 1800, 5ed, Cambridge University Press, 2005, 30-31. It is also documented that "between around 700 and 1500 AD, a majority of Muslim visitors to East Africa probably concerned with some aspect of trade". See for instance, Martin BG 'Arab migrations to East Africa in medieval times', 367, 375.

18 Taiwo EA, 'Justifications, challenges and constitutionality of the penal aspects of Shari'ah law in Nigeria' 17 Griffith Law Review 1 (2008), 184, 185. Regarding the introduction of Islamic customary law and its institutions, Yadudu has written: "The Islamic legal order was brought to the pre-colonial part of Nigeria with the conversion of the people to Islam. This began in the $9^{\text {th }}$ century with the Kanem Borno and spread in the $11^{\text {th }}$ century to the rest of the region. However, the widespread application of the Islamic law and the formalization of its judicial structures occurred only during the early part of the 19th century with the establishment of the Sokoto caliphate. This had occurred much earlier on a smaller scale under the Saifawa dynasty of Borno". See, Yadudu AH, "Colonialism and the transformation of Islamic law' 32 Journal of Legal Pluralism and Unofficial Law (1992), 103, 110. 
and parts of southern Africa ${ }^{19}$ - the advent of Europeans brought with it the mind and methods of Europe..$^{20}$ And the revolution was a fusion of material development, education and progress. ${ }^{21}$ These outcomes were expected given that part of the 'dual mandate' pursued by British imperialism was the,

[t]ask of civilisation to put an end to slavery, to establish courts of law, to inculcate in the natives a sense of individual responsibility, of liberty, of justice, and to teach their rulers how to apply these principles; above all, to see to it that the system of education should be such as to produce happiness and progress. ${ }^{22}$

None of these developments, however, posed substantial threats to African religion, custom and law save for in so far as they converted and assimilated 'natives' into the new cultures, oftentimes at the chagrin of the traditional ways of life. The conversion was mostly though persuasion and interaction. Even then, most Africans continued to practice their traditional customs as well as the new religions and cultures. The three civilisations, traditional African religion/customs, Christianity and Islam, would latter play a significant role in not only East Africa, but also the continent as a whole. Ali Mazrui has conceptualised that Africa can best be understood in the light of this 'triple heritage'. According to this account:

The twentieth century witnessed the full flowering of Africa's triple heritage (Africanity, Islam, and Westernization). This has developed into a major new paradigm for interpreting Africa - for viewing the continent as a convergence of three civilizations. ${ }^{23}$

19 Regarding the conquest of the relevant regions of Africa, Lugard has written: "During the first half of these thirty years, it was my privilege to assist in some degree in bringing under British control portions of Nyasaland, East Africa, Uganda, and Nigeria..." See, Lugard F, The dual mandate in British tropical Africa, 5ed, Frank Cass \& Co, 1965, 7.

20 Lugard, The dual mandate, 5.

21 Lugard, The dual mandate, 5.

22 Lugard, The dual mandate, 5.

23 Mazrui AA, 'The re-invention of Africa: Edward Said, VY Mudimbe, and beyond' 36 Research in African Literatures 3, (Fall 2005), 68, 76. Of this aspect, it has also been noted: "Professor Ali Mazrui ... argues that African culture today must be "understood best in terms of its 'triple heritage', of indigenous, Islam, and western forces, which had arisen out of an ancient confluence of indigenous, Semitic, and Greco-Roman forces." Consequently, the combination of these diverse cultures and current trends in globalisation have immensely disturbed the purity of African customary values. Thus, an African cultural tradition may, therefore, mean much more than extant traditional practices. Indeed, it may impute a blend of traditional African values, western way of life, and even Asiatic values or traditional practices." See, Juma L, 'Reconciling African customary law and human rights in Kenya: Making a case for institutional reformation and revitalization of customary adjudication processes' Saint Thomas Law Review (2002), 475. 


\section{Traditional African customary law during the colonial epoch}

The Berlin Conference (1884-85) could rightly be said to have officially flagged off the act and art of colonialism in Africa. Consequently, the British made Kenya a protectorate on 15 June $1895 .^{24}$ Thereafter, the British found out that traditional African societies did not have law in the Anglo-American sense. This allowed them to pass an Executive Order in Council in 1897 which proclaimed the reception of English law into Kenya and declared the supremacy of common law over customary law where there was an overlap..$^{25}$ This way, the British were able using foreign laws to permeate all spheres of African life, including marriage, property relations and criminal justice.

Colonialism had the profound effect of delivering the East African legal jurisdiction to the Crown at the Westminster. Henceforth, the Westminster institutions would make laws for East Africa, just as in the United Kingdom. Behind the façade of the imposition of western legal implements was the tacit articulation of foreign values and religion in East Africa. While there was nothing wrong with the introduction of foreign values (after all change had been happening in Africa ever since the initial acts of colonisation, and even further back with trade and conflict driven migration), the new masters sought to proscribe certain African cultural laws and practices. As illustrated by the $R v$ Amkeyo ${ }^{26}$ case discussed later in this contribution, the British accepted African customary law and religion to some extent, but also riddled it with the so called 'repugnancy clauses', in order to avoid those aspects of African customs that European culture found most appalling, ridiculous, or simply unhelpful to the inculcation of Christian ideals. ${ }^{27}$

However, colonial authorities made some concessions permitting local communities to observe their own customary laws in limited circumstances, and towards this end, a parallel system of courts was established to administer justice to the indigenous people. The Native Tribunals Ordinance empowered the tribunals to administer:

[t] he native law and custom prevailing in the area of the jurisdiction of the tribunal so far as it is not repugnant to justice or morality or inconsistent with the provisions of any Order in Council or with any other law in force in the colony. ${ }^{28}$

van Doren 'Death African style', 331.

van Doren 'Death African style', 331.

R v Amkeyo (1917) 7 EALR 14.

Ocran, 'The clash of legal cultures', 467-468.

Section 13(a), Native Tribunals Ordinance. 
A development similar to this (in South Africa) has been succinctly documented: ${ }^{29}$

In 1927, the Native Administration Act applied the system of indirect rule in a uniform way across the whole of what had by then become the Union of South Africa. An important feature of the place so accorded to indigenous law was the extent to which it was officially recognized. Only those parts of the law which did not conflict with colonial interest and control were given official support. The practical result was that white indigenous rules of marriage, family law, and succession were permitted to survive, the system of land ownership was indigenous in form only, and all significant jurisdictions over criminal matters passed into the hands of colonial officials.

It is instructive that local populations continued to observe their customs sometimes even adjudicating criminal conflicts according to their traditional norms. ${ }^{30}$

\section{State of African customary law in post-colonial Kenya}

Two kinds of emotions characterised the fortunes of African customary law in post-colonial Africa (including Kenya); first a fear for English common law by departing colonialists, and second a persistent fear for African customary law by those sympathetic to its wellbeing. The fear by the authors and stablekeepers of the colonial faith concerned the future of imposed laws given the euphoria and threats caused by independence and the prospect of indigenisation respectively. According to Okoth-Ogendo, it was feared that:

[t]he wave of nationalism then sweeping through black Africa would uproot colonialism's most precious contributions to the future development of the continent, namely the imposition of an Anglo-European system of law and legal ordering. For English-speaking Africa, it was feared that 'the common law of England and the doctrines of equity' might be swept away and replaced with a static, unwritten regime of 'native law and custom' the ascertainment of which depended on the fading memories of octogenarians living in a continent notorious for high mortality levels. ${ }^{31}$

But these fears would soon be assuaged, as it became manifest the emerging African elite preferred to operate the western systems in which they were schooled. Thus, once the euphoric waves associated with independence had settled, it was time for sympathisers of African customary law to lament the relega-

\footnotetext{
29 du Bois F, Visser D, 'The influence of foreign law in South Africa' Translational Law and Contemporary Problems (2003), 600.

30 van Doren 'Death African style', 332.

31 Okoth-Ogendo HWO, 'Customary law in the Kenyan legal system: An old debate revived' in Ojwang and Mugambi, The SM Otieno case, 135.
} 
tion of indigenous customary laws and systems, which had, and continue to be, effected in multifarious ways. Since independence, African customary law has suffered tremendous usurpations on the juridical front. These limitations have been possible because of the Constitution, Acts of Parliament, judicial decisions, and the human rights movement. The following subsection now turns to address each of these items and how they have affected the healthy stay of African customary law.

\section{The Constitution}

The Constitution of Kenya ${ }^{32}$ is the most significant legal instrument in the legal system. The foremost legislation impacts on traditional African religion and customary practices in three ways significant to this study. Firstly, according to its Article 2(1), the Constitution "is the supreme law of the Republic and binds all persons and all State organs at both levels of government". Thus, "any law, including customary law, that is inconsistent with this Constitution is void to the extent of the inconsistency". ${ }^{33}$ African customary law has, therefore, to conform to the Constitution if it has to be considered legally sound and valid. Otherwise, such practices remain void to the extent of their inconsistency with the Constitution. Put differently, the Constitution offers the first most important yardstick against which the relevance of all other laws, religions, customs, and practices are measured. For instance, although the Constitution allows Parliament to enact legislation recognising marriages conducted under any tradition, or system of religious, personal or family law, ${ }^{34}$ such marriages must be consistent with the Constitution to be acceptable. ${ }^{35}$

Secondly, the Constitution stipulates that no one shall be tried for a criminal offence unless it amounts to an offence under the laws of the State or under international law. ${ }^{36}$ This provision alone has the effect of rendering the entire African customary criminal law invalid. This is because African customs are hardly written and even then only recognised formal legislative structures such as Parliament are allowed to enact criminal law. It implies that the entire corpus of African customary offences is dead except for those traditional crimes that

32 Revised Edition 2010, Published by the National Council for Law Reporting with the Authority of the Attorney General.

Article 2(4), Constitution of Kenya (2010). Emphasis added.

Article 45(4)(a), Constitution of Kenya (2010).

Article 45(4)(b), Constitution of Kenya (2010).

Article 50(2)(n), Constitution of Kenya (2010). 
have secured legislative articulation. As explained earlier in this contribution, African societies recognised numerous offenses and crimes, which were handled by local people according to traditional norms. ${ }^{37}$ These crimes are no longer acknowledged given the supremacy of the Constitution and Parliament in the penal realm; and especially after the independence state failed to seize an initial window in the Independence Constitution paving way for the codification of African customary crimes within the three-year grace period stipulated. ${ }^{38}$ Thus, the subject became entirely extinguished on 12 December $1966 .{ }^{39}$

The third way in which the Constitution restricts customary law and religion is through certain other subtle provisions whose overall effect is to sideline traditional practices. An example of such provision is one in the Bill of Rights requiring that the youth be "protected from harmful cultural practices". ${ }^{40}$ Among the harmful traditions from which the youth are to be protected, obviously, are practices such as female genital mutilation, a central custom in many African traditions. Similarly, under the Constitution, the right to marry is a preserve of persons of opposite sex, meaning that woman-to-woman marriages prevalent in most African communities are not authorised. This obstacle to customary law was however partly surmounted in Monica Jesang Katam v Jackson Chepkwony \& Another, ${ }^{41}$ where JB Ojwang J (as he then was) did not hesitate to protect the inheritance rights of a woman married to another under Nandi customary law, a juridical process that could have legitimised such practices. The judge found that the petitioner "was a 'wife', and, by the operative customary law, she and her sons belonged to the household of the deceased, and were entitled to inheritance rights, prior to anyone else". Same sex marriage could therefore be read into the scheme of the Law of Succession Act, ${ }^{42}$ placing the petitioner and her children in the first line of inheritance: the petitioner herself for being 'wife of the deceased', and her children for being the children of the deceased. Under this genre of customary marriages:

A woman past the age of [among the Nandi and Kipsigis] child-bearing and who has no sons, may enter into a form of marriage with another woman. This may be done during the lifetime of her husband, but is more usual after his death. Marriage consideration is paid, as in regular marriage, and a man from the woman's husband's clan has intercourse with the girl in respect of whom marriage consideration has been paid. Any children born

van Doren 'Death African style', 332.

Cotran E, The law of marriage and divorce, Vol. 1 Sweet \& Maxwell, London, 1968, 155.

Cotran, The law of marriage and divorce, 155.

Article 55(d), Constitution of Kenya (2010).

[2011] eKLR

Section 29, (Cap 160). 
to the girl are regarded as the children of the woman who paid marriage consideration and her husband. ${ }^{43}$

There are however, certain concessions in the Bill of Rights tending to give Islamic customary law a place in the legal system. The Bill of Rights' equality provisions are for example qualified to the extent strictly necessary for the application of Islamic law before Kadhi's courts, to persons who profess the Islamic faith, in matters relating to personal status, marriage, divorce and inheritance. $^{44}$

\section{Parliamentary/legislative enactments}

The onslaught against African customary law has not been the preserve of the Constitution. Numerous Acts of Parliament have been enacted some which deal a severe blow to African customary law and religion. This incidence, it would appear, has not been a practice peculiar to Kenya. In Mthembu v Letsela, Judge Mynardt reckoned a similar development in southern Africa:

The radical amelioration of the common law has hitherto been a function of Parliament; there is no reason to believe that Parliament will not continue to exercise that function. ${ }^{45}$

In postcolonial Kenya, the earliest legislation to directly alter African customary law was the Magistrates Courts Act (1967), which gave magistrates the jurisdiction to entertain claims under customary law. At Section 2 of this legislation, a "claim under customary law" is defined as any claim concerning: land held under customary tenure; marriage, divorce, maintenance or dowry; seduction or pregnancy of unmarried woman or girl; enticement of or adultery with a married woman; and divorce under customary law. This provision has evoked great confusion. ${ }^{46}$ Questions have arisen regarding whether the list effectively dismisses the adjudication of other strands of African customary law in the magistrate's court, more so given the fact that it omits certain pertinent matters such as claims affecting children, compensation, adoption and testate succession. ${ }^{47}$

Besides the magistrate courts, the jurisdiction of other courts was determined by the Judicature Act of 1967 which stipulates:

\footnotetext{
Cotran, The law of marriage and divorce, 117.

Article 24(4), Constitution of Kenya (2010).

45 Cited in Omotoal JA, 'Primogeniture and illegitimacy in African customary law: The battle for survival of culture' Indiana International and Comparative Law Review (2004), 120.

46 Juma, 'Reconciling African customary law', 466-467.

47 Juma, 'Reconciling African customary law', 466-467.
} 
The jurisdiction of the High Court, the Court of Appeal and of all subordinate courts shall be exercised in conformity with - (a) the Constitution; (b) subject thereto, all other written laws, including the Acts of Parliament of the United Kingdom cited in Part I of the Schedule to this Act, modified in accordance with Part II of that Schedule; (c) subject thereto and so far as those written laws do not extend or apply, the substance of the common law, the doctrines of equity and the statutes of general application in force in England on the $12^{\text {th }}$ August, 1897, and the procedure and practice observed in courts of justice in England at that date; but the common law, doctrines of equity and statues of general application shall apply so far only as the circumstances of Kenya and its inhabitants permit and subject to such qualifications as those circumstances may render necessary.

The High Court, the Court of Appeal and all subordinate courts shall be guided by African customary law in civil cases in which one or more of the parties is subject to it or affected by it, so far as it is applicable and is not repugnant to justice and morality or inconsistent with any written law, and shall decide all such cases according to substantial justice without undue regard to technicalities of procedure and without undue delay. ${ }^{48}$

This piece of legislation commits at least five cardinal wrongs against African customary law. Firstly, going by the order in which the different sources of law are mentioned, it creates a hierarchy of norms according to which African customary law is of least significance. The very isolation of African customary law, as a source of law, to a different and latter sub-section is testimony to this fact. It does not help matters that even English Acts of Parliament applicable on or before 12 August 1897 are superior to indigenous law. Further, English customary law in the nature of common law and doctrines of equity comes before African customary law in terms of ranking. Yet, as Horsfall J once noted, these doctrines embody Christian values. In the Judge's own words:

It would be wrong to apply principles of equity, which were devised to suit Christian society in England during the last century in order to import a presumption whereby to gauge the intention of a Muslim husband and wife living in present day Zanzibar whose social and cultural background is very different from that of Victorian England. ${ }^{49}$

Secondly, the law reasserts the prime status of the Constitution as a source of law. This study has already noted that the Constitution contains provisions that are out rightly insensitive to African customary practices.

Thirdly, the Act does not list African customary law as a binding source of law. Rather, courts of law are merely required to be 'guided' by this body of law. That wording is unique to African customary law and must be telling of its

\footnotetext{
Section 3(1) and (2), Judicature Act (Cap 8).

49 Raya Binti v Hamed Bin Suleiman (1962) EA 248.
} 
insignificance in Kenya's legal system. As a way forward, Cotran suggested that "the word 'guided' in Section 3(2) of the Judicature Act should be replaced by the word 'apply". 50

Fourthly, the section reiterates the fact that African customary law shall only be limited to civil matters that affect either party to a dispute. In other words, African customary civil law would apply to only those who are affected by or subjected to it. This, again, is an affirmation that the entire body of African customary criminal law has no application in Kenya.

Fifthly, the legislation introduces the 'repugnancy clause', which has invariably served as slow poison against the quest to apply African customary law. The repugnancy test usually entails weighing African customary practices against the 'ideal' that is western values. According to Justice Ocran of Ghana:

The repugnancy clauses were meant to rule out laws and customs perceived to be against Christian values and morality or cruel and unusual standards of the colonizers. There were various formulations of these clauses. Some stated that the rules should not be repugnant to "natural justice, equity and good conscience." Others read: "Not contrary to [religious] justice, morality or order." Still others read: "Not repugnant to morality, humanity or natural justice or injurious to the welfare of the natives." ${ }^{51}$

Ruling on a related issue, a British judge in an East African colonial court (in 1938) frankly stated that:

I have no doubt whatever that the only standard of justice and morality which a British court in Africa can apply is its own British standard. Otherwise we should find ourselves in certain circumstances having to condone such things, for example, as the institution of slavery.

On this basis, then, the justice of applying to the present circumstances the native 'law' which has been postulated in this case must be decided. Is it just according to our ideas to take away a man's property in order to compensate a party who has suffered injury at the hands of a man's son, the son being of full age and fully responsible in law for his own actions? I hold most strongly the opinion that it is not just. ${ }^{52}$

Yet another colonial ruling failed not conceal its contempt for certain indigenous practices: Said the Privy Council in Re Southern Rhodesia;

Some tribes are so low in the scale of social organisation that their usages and conception of rights and duties are not to be reconciled with the institution or legal ideas of civilised society. ${ }^{53}$

\footnotetext{
Cotran, The law of marriage and divorce, 150.

Ocran, 'The clash of legal cultures', 475.

Gwao bin Kilimo v Kisunda bin Ifuti (1938) 1 TLR (R) 403.

(1919) AC, 211
} 
Following this train of thought, in Kenya, the test for repugnancy has mostly been one of common law. During the colonial era, the test governing when a custom is deemed repugnant to morality or justice was whether it could be said to be repugnant "as the people of England see it." ${ }^{54}$ The case of $\mathrm{R} v$ Amkeyo illustrates this point perhaps more than any other precedent. In this decision, a colonial court ruled that a marriage in respect of African customary law could not stand because native traditions cannot support a marriage in the proper sense of the word. Hence, the colonial court, apart from declaring such a 'marriage' repugnant to justice and morality, also went further to describe such a relationship pegged on payment of dowry (and not limited in the number of women one can marry) simply as 'wife purchase'. Chief Justice Hamilton's entered the following memorable dicta:

In my opinion, the use of the word 'marriage' to describe the relationship entered into by an African native with a woman of his tribe according to tribal custom is a misnomer which has led in the past to considerable confusion of ideas. I know of no word that correctly describes it; 'wife-purchase' is not altogether satisfactory, but it comes much nearer to the idea than that of 'marriage' as generally understood among civilised peoples.

As far as the Kenyan legal system is concerned, the substance of African customary law remains principally in the fields of contract law, tort law, family law and land law. ${ }^{55}$ But even in these spheres, statutory law has been eating away ground. For instance, the (2001) enactment of the Children Act withheld all manner of items pertaining to children from the domains of African customary religion and law. The Law of Succession Act, passed in 1981, currently supersedes all forms of applicable customary, Hindu or Islamic laws of succession. In the end, African customary law is left with very limited spheres of influence in the legal system and perhaps Okoth-Ogendo was accurate in observing that at the rate at which legislatures in Africa were churning out statutes based on Anglo-European jurisprudence, customary law would be lying "in a juridical morgue waiting to be buried beneath unyielding legislative tombstones". ${ }^{56}$

\section{The human rights discourse}

The discourse on human rights in Kenya is currently dominated by sustained condemnation of the institutions of customary law and religion that have failed

This was the test enumerated in Regina v Luke Marangula, Reports of Northern Rhodesia (1949-54), 140.

55 Juma, 'Reconciling African customary law', 480.

56 Okoth-Ogendo, 'Customary law in the Kenyan legal system', 136. 
to satisfy the demands of international human rights law. ${ }^{57}$ Undeniably, argues Juma, such condemnation has exalted pursuits for gender-sensitive programmes and policies, heralded the demand for the repeal of unjust legislation, and bolstered general awareness of international human rights instruments - albeit to some significant levels. ${ }^{58}$ In the process, traditional religious and customary practices such as female circumcision amongst the Maasai, wife inheritance amongst the Luo, traditional boy initiation amongst the Bukusu, and polygamy amongst many African civilisations have suffered tremendous bereavements.

Additionally, the post colonial reception of constitutional and human rights law provides the framework in which the legal capacity of the colonial transplantation of European law into a territory with its own indigenous legal traditions is still being confronted. Obviously, courts of traditional leaders can no longer be permitted to exercise functions in terms of indigenous law that fall foul of the trias politica principle that is applied to courts of European descent. ${ }^{59}$ It suffices to state that the human rights discourse is one major front through which customary law and religion continue to suffer.

\section{Case law}

It is already clear that African customary law in Kenya can also be understood through the prisms of judicial precedents. This contribution has already alluded to $R v$ Amkeyo, a judicial decision that belittled African customary law during the colonial period. The most significant decision in the postcolonial era, perhaps, is the Otieno case. ${ }^{60}$ When SM Otieno a prominent lawyer died in 1986, a protracted legal battle ensued over his place for burial. This dispute pitted the widow, Wambui Otieno, against the deceased's brother and members of the deceased's clan. Specifically, they objected to her announced intention to bury the remains of her late husband in Nairobi. Efforts to resolve the matter amicably failed after the widow labelled the clan members as thieves merely interested in 'looting' her house. Consequently, she filed suit in the High Court seeking a declaration entitling her to claim her husband's body from the City Mortuary and perform the burial ceremony. She also sought injunctive orders restraining the clan from ever removing or in any way interfering with the remains of the deceased until the dispute was resolved. The clan contested this claim on the

\footnotetext{
57 Juma, 'Reconciling African customary law', 493.

58 Juma, 'Reconciling African customary law', 493.

59 du Bois, Visser, 'The influence of foreign law in South Africa', 594, 595

60 For a detailed analysis of the case, see Juma, 'Reconciling African customary law', 482.
} 
grounds that the deceased was a Luo, and, thus, needed to be buried in accordance with Luo custom. They indicated that Luo custom demanded that a person of the deceased's stature had to be buried in his ancestral home.

The protagonists articulated their claims differently. While the widow's claim was based on the English common law right of a wife to bury her husband, the clan members appealed to the customarian responsibility imparted by the instrumentality of Luo customary law. The case was adjudicated up to the highest court of the land, the Court of Appeal, which decided in favour of Luo customary law. The Court argued that when it comes to matters of personal law such as death and burial rites, it is the customary law of the deceased that applies.

This finding is a mixed bag in that it impacts on African customary law in at least five divergent ways. One, the decision is evidence of the fact that African customary law could still have a place in Kenya's legal system, after all. Two, the decision laid to rest the argument that customary law can be held to be repugnant to justice and morality in cases where it simply differs from western rules on the subject. ${ }^{11}$ In fact, the Otieno case found that the two systems of law, common law and African customary law were not mutually exclusive and that they were meant to compliment each other. However, the decision did not settle the question regarding the juridical status of African customary law vis-à-vis other legal norms in the hierarchy of norms. Three, as Eugene Cotran has argued, the judgement drew a line through the colonial notion, spelled out in the case of Cole v Cole in 1898, that an educated, urbanised African escapes customary law. The Court of Appeal rejected this approach arguing instead that it matters not that the deceased was sophisticated, urbanised and developed a different lifestyle. ${ }^{63}$ The tribunal held that "it seems to us quite unsustainable... that a different formal education and an urban lifestyle can affect adherence to one's personal law". ${ }^{64}$ Four, the very act of adjudicating African customary law before modern tribunals fashioned on western constitutional ideals robs African customary law of its very innate character. African customary law is ideally an unwritten discipline. ${ }^{65}$ Disputes under this tradition are usually determined by traditional structures that mostly seek reconciliation rather than a 'winner takes all' mentality. By litigating this dispute before a modern tribunal composed of members not culturally or-

\footnotetext{
Manji A, 'Of the laws of Kenya and burials and all that' Law and Literature (2002), 465.

Cole v Cole (1898) 1 NLR 15.

Manji, 'Of the laws of Kenya and burials', 465.

Cotran E, Casebook on Kenya customary law, 1988, Case No. 88.

Ocran, 'The clash of legal cultures', 467-468.
} 
dained to interpret such traditions, African customary law lost its very essence. Five, the decision did not endeavour to expand the scope of African customary law, but rather, limited its interpretation of customary law only to matters concerning personal law. Hence, the decision is not indicative of whether there is a possibility of expanding customary law to other areas, some of which, as stated above, statutory enactments have since rushed to occupy.

\section{In lieu of conclusion}

In lieu of conclusion, it is submitted that the ideal of Dini ya Musambwa of having African customary law regain prominence has not been achieved just as the faith has yet to be accepted. Quite to the contrary, each coming day witnesses the crucification of African customs in preference of novel values mostly originating from western traditions and value systems. Indigenous practices whether religious, moral or customary have to contend with the fact that there are official restrictions both express and tacit. In this regard, one may safely argue that customary freedom is not achievable by a significant portion of the mostly rural populations in Kenya. Although both international law and the Constitution provide for the right to culture and cultural experience, it is not very difficult to argue that African customary law has received more limitations than are necessary in a free and democratic society.

Given this scenario, it might be appropriate for the country to reassess the potential value of traditional systems in the now fast-changing world. Kenya's legal system faces substantial challenges in the area of dispute resolution such as backlog of cases, delays in the adjudication of matters, high costs of litigation and alien juridical languages and convoluted procedures. To these hurdles, the authors of the 2010 Constitution prescribe prompt dispensation of justice; the promotion of alternative forms of dispute resolution including reconciliation, mediation, arbitration and traditional dispute resolution mechanisms; and the administration of justice without undue regard to procedural technicalities; among others, as viable solutions. ${ }^{66}$

Perhaps African customary law and institutions could be seized to give effect to these constitutional requirements. Such structures, where available, are capable of being deployed in adjudicating small claims and other civil matters in

66 Article 159(2), Constitution of Kenya (2010). 
the areas of family, succession, death and burial without much regard to prohibitive formalities and technicalities of procedures.

There is equally room for consistent development of the common law of Kenya through judge-made law as Okoth-Ogendo suggested way back, there being sufficient areas of consensus in these matters. Already, Ojwang J has led the way by, for instance, refusing to be persuaded, in Janet Ngubia Githieya $v$ Wairimu Gitau, that,

[t]he practice of cremation, which is well recognised worldwide, and which appears to be a hygienic and an environmentally-wholesome mode of disposal of the dead, cannot in these modern times be accommodated under the evolving Kikuyu customary law or indeed any other customary law in force in this country. ${ }^{67}$

The Jesang precedent, discussed above, is also instructive that with necessary modifications to both the 'received' common law and African customary law, it is possible to reinvent the family, as well as resolve the numerous land issues that clog our judicial systems.

Some legislative reforms are also tenable. As Cotran suggested way back in 1989, Parliament should make up its mind on what aspects of customary law should apply. This should effectively do away with repugnancy clauses and other criteria demeaning to African customary law.

HCCC No. 667 of 2004. 